Harvard Kennedy School Misinformation Review ${ }^{1}$

August 2021, Volume 2, Issue 4

Creative Commons Attribution 4.0 International ( $\underline{\mathrm{CC} \text { BY 4.0) }}$

Reprints and permissions: misinforeview@hks.harvard.edu

DOI: https://doi.org/10.37016/mr-2020-76

Website: misinforeview.hks.harvard.edu

\title{
Critical disinformation studies: History, power, and politics
}

This essay advocates a critical approach to disinformation research that is grounded in history, culture, and politics, and centers questions of power and inequality. In the United States, identity, particularly race, plays a key role in the messages and strategies of disinformation producers and who disinformation and misinformation resonates with. Expanding what "counts" as disinformation demonstrates that disinformation is a primary media strategy that has been used in the U.S. to reproduce and reinforce white supremacy and hierarchies of power at the expense of populations that lack social, cultural, political, or economic power.

Authors: Rachel Kuo (1), Alice Marwick $(1,2)$

Affiliations: (1) Center for Information, Technology, and Public Life, University of North Carolina-Chapel Hill, USA, (2) Department of Communication, University of North Carolina-Chapel Hill, USA

How to cite: Kuo, R., \& Marwick, A. (2021). Critical disinformation studies: History, power, and politics. Harvard Kennedy School (HKS) Misinformation Review, 2(4).

Received: May 20 ${ }^{\text {th }}$ 2021. Accepted: July 23 ${ }^{\text {rd }}$, 2021. Published: August $12^{\text {th }}, 2021$.

\section{A critical approach to disinformation}

Disinformation has been a major scholarly and public area of concern since 2016, spurred by a resurgence of white, right-wing nationalism exemplified by Brexit and Trump's presidential victory (Kreiss, 2021). The term "disinformation" refers to false or misleading information intentionally spread for profit, to create harm, or to advance political or ideological goals (Freelon \& Wells, 2020). While this encompasses many information types, in public discourse disinformation is tied inextricably to social media and technology platforms, and often curiously depoliticized, framed as "polluting" or "infecting" an otherwise healthy information ecosystem. This framing disconnects disinformation from the broader politics of knowledge production and systems of power that undergird it; in other words, who benefits and why?

A great deal of research suggests that disinformation narratives build on and reify pre-existing ideologies, frequently involving race and inequality (Freelon et al., 2020; Nkonde et al., 2021; Ong, 2021). Identity-based hierarchies, particularly race, play a key role in the creation, spread, and uptake of disinformation narratives (Kreiss et al., 2020; Marwick et al., 2021). This essay explores how this body of scholarship is central to understanding key issues and debates in disinformation research, including polarization, media ecosystems, and relevant actors.

\footnotetext{
${ }^{1}$ A publication of the Shorenstein Center for Media, Politics and Public Policy, at Harvard University, John F. Kennedy School of Government.
} 
Drawing from principles established by the Center for Information, Technology, and Public Life at the University of North Carolina-Chapel Hill, we argue that analyses of disinformation are more effective when they include:

1. Grounding disinformation studies in history, society, culture, and politics;

2. Centering analyses of how social differentiation, such as race, gender, and class, shape dynamics of disinformation;

3. Foregrounding questions of how institutional power and economic, social, cultural, and technological structures shape disinformation; and

4. Stating and maintaining explicit commitments to justice and equality.

By taking a historical and contextual view of disinformation, we argue that both the content and framing of disinformation reproduce whiteness in the United States. White supremacy is built upon assumptions that elevate and empower white perspectives as normal and standard. This assumption, referred to as whiteness, is not an individual racial identity, but a fundamental part of broader, historically rooted systems of power that privilege white perspectives (Ahmed 2007; Harris, 1993). When we ignore the content of disinformation and treat it as a mysterious and ineffable toxin, we cannot understand why it resonates, where it comes from, or how it spreads (e.g., del Vicario et al., 2016; Vosoughi et al., 2018). Characterizing disinformation as a toxin also assumes a shared, healthy information ecosystem, which ignores historical and ongoing ideological and political inequalities that center white viewpoints. Reframing "disinformation" from a problem of information pollution to a form of knowledge that is propagated and circulated requires addressing questions of power from "nonnormative" and "marginal" positions, such as queer or feminist of color communities (Cohen, 1997).

Our commentary primarily uses examples in the United States and is written by U.S.-based scholars. However, a truly critical approach to disinformation studies must take into account that deliberately false information is culturally and politically specific; analytic concepts developed in the U.S. may limit our understanding and proposed solutions, as the forms of inequality leveraged and furthered by disinformation are deeply contextual (Marwick et al., 2021).

\section{(Re)Defining disinformation studies}

The victory of Donald Trump over Hillary Clinton in the 2016 U.S. Presidential election took elites by surprise. The popular theory that Trump won because he appealed to the economic anxieties of a "white working class" (Coontz, 2016; Frank, 2016) has been contested (Carnes \& Lupu, 2021). Evidence suggests that Trump's electoral college victory was instead due to his messaging to white voters that traditional white American economic, political, and social status was under threat (Mutz, 2018; Schaffner et al., 2018; Sides et al., 2018). Another set of explanations focuses on the role of mis- and disinformation on social platforms (Read, 2016; Solon, 2016). Many of these narratives imply that: 1) in the past everyone shared the same sense of what was true and false; 2) this shared understanding of knowledge was reinforced, if not established, by legacy media like newspapers and TV news; 3) "fake news," disinformation, and inauthentic behavior on social platforms are responsible for a global shift to far-right populism. However, these assumptions do not paint a full picture of why and how disinformation propagates. Further, focusing intently on the present ignores and obscures the historical foundations of these shifts.

First, positing a current crisis of fragmented "truth" due to technologically enabled polarization presumes that, prior to the advent of social platforms, the public agreed upon "facts" and "knowledge." However, this ignores the role that legacy media has played in maintaining inequality. Historically, the white press portrayed Black people as dangerous criminals and justified and supported violence against Black communities (Staples, 2021). As Mejia et al. point out (2018), dominant U.S. politics have always relied on the existence of multiple realities. For instance, U.S. drug policy is predicated on a false "truth" of Black dealers spreading drugs to white communities, while the myth of Black "superpredators" in the 
1990s justified an enormous expansion of the U.S. carceral system under Clinton (Duru, 2004). Spaces like the Black press presented alternative perspectives to white-dominant media, covering stories ignored by the white press and countering such racist depictions (Alamo-Pastrana \& Hoynes, 2020, Staples, 2021). These examples of multiple racial realities exemplify how different forms of "truth" and knowledge have always co-existed with uneven impacts and values.

Second, the "deep stories" and "deep frames"-the repetition of particular narratives and stereotypes-behind much of disinformation amplifies and bolsters pre-existing racist, misogynist, xenophobic, or transphobic tropes (Phillips \& Milner, 2021; Polletta \& Callahan, 2017). Like more traditional forms of news and politics, such narratives resonate with people precisely because they play on appeals to whiteness and other forms of structural power (Jardina, 2019; Kreiss et al., 2020; Peck, 2019). For example, Qanon conspiracy theories combine 1980 s conservative "satanic panic" with centuries-old anti-Semitic tropes of "blood libel" (Hughes, 2017; Lavin, 2020). Fears of "migrant caravans" and dangerous undocumented immigrants play on white racial fears with deep historical roots to justify systemic racism (Flores-Yeffal et al., 2019). Such disinformation campaigns do not exist in a vacuum but are successful precisely because they are congruous with extant inequalities.

Third, corporations, state actors, and politicians have always spread false and misleading narratives to achieve their ideological goals. This is not just a problem with social media platforms. For example, during the second Iraq War, the Bush administration claimed that Hussein's regime had weapons of mass destruction, planted false stories about heroic U.S. soldiers in the mass media, and heavily limited critical coverage of war casualties and anti-war efforts (Kumar, 2006; Snow \& Taylor, 2006). Given the Trump administration's well-documented role in creating, spreading, and amplifying disinformation, it is important that scholarly and popular emphases on social platforms do not overlook these well-established precedents. Additionally, while legacy media institutions play an important role in criticizing government administrations, they can also spread state-sanctioned narratives. During World War II, for instance, the press served as the "guard dog" of the state, lending credence to the government's claim that Japanese American citizens presented a security threat, and justifying mass incarceration and forced removal (Bishop, 2000). The media, U.S. military, and elected officials used euphemisms such as internment, relocation, and evacuation to distort and misrepresent this punitive injustice-which persist in contemporary textbooks and news sources to this day (Densho, 2021; Japanese American Citizens League, 2013).

Examining the larger media ecosystem, including the role of broadcast media, can help us better understand sites of study within disinformation research, such as how fringe communities explicitly manipulate media to expose larger audiences to extremist viewpoints - a tactic known as "trading up the chain" (Marwick \& Lewis, 2017 Friedberg \& Donovan, 2020). Hyper-partisan media, in particular, often spreads disinformation narratives: Fox's Sean Hannity repeated the conspiracy theory that Hillary Clinton's campaign murdered Democratic staffer Seth Rich, and upstart conservative cable networks OANN, Newsmax, and Blaze heavily amplified the "Stop the Steal" movement (KhudaBukhsh et al., 2021). Focusing primarily on Facebook and Twitter ignores the role of other media forms and networks and the reality of how information circulates both on and offline (Feng \& Tseng-Putterman, 2019; Pasquetto, 2020).

Just as pinning Trump's victory on "economic anxieties" makes it possible to ignore intersections of race and class and blame poor, working-class communities, disregarding the content of disinformation makes it possible to ignore why it succeeds. Instead, integrating cultural and historical approaches into the study of mis- and disinformation appeals to inequality as well as the political economy of social platforms that facilitates their spread. We begin by tracing how the powerful have historically used "knowledge" to establish, justify, and support racial inequality and colonialism. We then discuss the disproportionate and uneven harms of contemporary disinformation and conclude with recommendations and possibilities for future research. 


\section{Racial and imperial histories of information}

Knowledge and information production is an active process that is political, serving and benefitting specific interests. "Knowledge" and even "history" are produced by social and political actors and used to legitimize and validate social inequality (Almeida, 2015; Du Bois, 1935; Trouillot 1995). For instance, European imperial powers used images, speech, and text to reinforce who was "colonizer" and "colonized" and establish racial hierarchies, dehumanizing Indigenous peoples and delegitimizing Indigenous histories, knowledges, and societies (Tuhiwai-Smith, 1999). The West justified such practices by producing racist pseudoscience that naturalized colonial practices, set itself in a superior position of power, and justified the expansion of its empire (Said, 1978; Saranillio, 2018).

Viewing disinformation through this lens of power and knowledge production illuminates how knowledge is used to justify racial divisions and structural inequality-both historically and in the present. Contemporary disinformation narratives propagate "old" racial and colonial tropes on new media using memes and hashtags (Flores-Yeffal, et al 2019; Tuters and Hagen, 2019). Repeatedly, disinformation is used to legitimate and rationalize violence. Incidents such as the January 6, 2021 white supremacist insurrection on the U.S. Capitol and mass shootings of people of color highlight the insidious, devastating real-world consequences of racist information (Fausset et al., 2021; Kreiss \& McGregor 2021). Anti-Muslim conspiracy theories on Facebook India against Rohingya communities have included calls to violence, like those leading to the Rohingya genocide in Myanmar (Equality Labs, 2019).

Viewing disinformation through a historical lens also demonstrates how, beyond explicitly malicious intent, disinformation narratives are frequently used by politicians to produce tacit public acceptance of policies instantiating inequality. For example, disinformation such as anti-Black, misogynistic and antipoor stereotypes like the "welfare queen" and anti-immigrant narratives about "invaders'" taking away jobs and resources have accompanied huge reductions in public benefits (Covert, 2019). Common myths surrounding individual responsibility and economic uplift buttress welfare reform policies like the 1996 Personal Responsibility and Work Opportunity Reconciliation Act, which left many people without adequate access to social safety nets (Cassiman, 2008). Racialized media tropes and portrayals play out in institutional spaces and systems, such as courtrooms, where dominant narratives of Black criminality are reproduced (Noble, 2014). For instance, media coverage of police shootings is heavily influenced by the perspectives of law enforcement (Adamson, 2016). Examining how contemporary disinformation is bound up with such longer histories highlights that information spreads and operates in ways that disproportionately harm already marginalized communities.

\section{Differential impacts of disinformation}

Disinformation is fundamentally related to power. Many scholars have chronicled that uneven access to information has real, material impacts (Gibson and Martin, 2019; Perez \& Dionisopoulos, 1995). The spread of mis- and disinformation within and about marginalized communities has similarly concrete impacts, which disproportionately fall on these communities and reify whiteness (Collins-Dexter, 2020; Nkonde et al., 2021; Ong, 2021).

The COVID-19 pandemic has shown us that these processes have life-or-death stakes. Brandi CollinsDexter (2020) points out that the disproportionate risk of death of Black people from COVID-19 is compounded by medical misinformation and conspiracies spreading in Black online spaces. She emphasizes that long-standing histories of trauma experienced by Black communities at the hands of media and government institutions create significant gaps in access to information and resources, exacerbated during moments of crisis. 
Racist disinformation spread during the pandemic also pivots on existing stereotypes. The Trump administration's racist characterization of COVID-19 as "Kung Flu" and "Chinese Virus," distorted information about "bat soup" in Wuhan, and characterization of Asian restaurants in the U.S. as 'dirty', all draw from long histories of xenophobic public health discourses coinciding with the racialized exclusion of Asians as "unwelcome," "undesirable," and "unfit" (Shah, 2001; Noel, 2020). Similarly, Islamophobic COVID-related disinformation, such as false claims of Muslims as "bioterrorists" spread by the hashtag \#Coronajihad, leverages existing religious and caste hierarchies as well as the unequal distribution of power and access on digital platforms (Equality Labs, 2020).

The Trump administration's initial refusal to take the COVID-19 pandemic seriously, referring to it as a "hoax," is eerily similar to the Reagan administration's refusal to acknowledge AIDS, where government mismanagement and the racialization of responsibility worsened conditions for already vulnerable communities (Bhaman \& Sabal, 2020). The AIDS epidemic exemplifies how disinformation spread by politicians and mainstream media is linked to discriminatory policies and resource distribution.

In 1986, the CDC announced the "four H's" of HIV-risk: "hemophiliacs, heroin users, homosexuals, and Haitians" - these "four H's" were not only misleading, but extremely harmful characterizations, leading to the detention of HIV-positive Haitian refugees in Guantanamo Bay. This criminalization of Haitian refugees as "dangerous" converged with the stigmatization of HIV/AIDS to sustain racially motivated migration policy rooted in both xenophobia and anti-Blackness. Historically, epidemiological narratives around HIV/AIDS center white, gay men, with people of color almost absent from the record and women excluded from diagnostic criteria until 1993 (Cheng, 2020). This obscured the crisis of welfare and resource distribution at the heart of the HIV/AIDS pandemic, where continued racial and socioeconomic inequalities blocked access to housing and healthcare. Activists and organizers created community projects, information networks, and public media spectacles to provide care and resources to their communities and combat the silencing and stigmatization furthered by government and mainstream media (Juhasz, 1995; Brier, 2009; McKinney, 2020).

The erosion of public trust in institutions is deeply significant. While disinformation may contribute to a decline in public trust, different communities may have low levels of public trust due to historical and contemporary experiences with government and media institutions may have very good reasons to distrust government and media due to historical contexts. During the Cold War, for example, the U.S. spread propaganda spinning domestic race relations in a positive light to legitimize the war on communism and justify military intervention in Asia (Ziegler, 2015; Dudziak, 2011). Radical Black movements attempted to combat this propaganda by explicitly challenging U.S. racial violence at home and abroad, which was considered so threatening that the state created the FBI COINTELPRO program to police activist groups (Frazier, 2014; Lieberman, 2014; Ziegler, 2015). These histories connect with uneven forms of political suppression that continue today, such as disinformation campaigns that strategically target Black voters to maintain hegemonic power (Worland, 2020).

\section{Recommendations and looking forward}

The different examples in this essay illustrate the histories and contexts in which power, politics, and information converge and how structural power is reproduced and reinforced across institutions. They offer entry points to studying disinformation that focus on the knowledge, experiences, and practices of groups who historically and currently bear the brunt of being targeted and oppressed by mis- and disinformation and propaganda campaigns. In doing so, these approaches may help us better evaluate potential interventions and solutions.

First, countering mis- and disinformation goes beyond solutions like "fact checking" or "media literacy" which place responsibility on individuals to become informed media consumers. In one 
devastating example, QAnon groups already assess and evaluate information validity and quality to defend, promote, and spread conspiracy theories (Marwick \& Partin, 2020). Similarly, online search, which is frequently used to assess information accuracy, is by no means neutral (Tripodi, 2018). In fact, it can lead to deadly results, as seen with Dylann Roof, the perpetrator of a mass shooting at a Black church in Charleston, South Carolina, whose Google search for "black on white crime" resulted in white supremacist propaganda (Noble, 2017). Rather than focusing on individual actions around information literacy and consumption, it may be more productive to examine the power structures that facilitate disinformation's spread, such as large technology companies, state actors, and media and information systems (McMillan Cottom, 2020).

Second, technology did not create the problem of disinformation and technical solutions alone are not the answer, especially as they can exacerbate existing harms (Tufekci, 2019; Washington \& Kuo, 2020). For example, technical attempts to "counter violent extremism" or "end radicalization" expand racialized criminalization (Kundnani, 2014; Nguyen, 2019). As Moustafa Bayoumi (2015) points out, information infrastructures built after $9 / 11$ to "counter terrorism" target Muslims, leveraging racialized narratives of terrorism to justify increasing national security apparatuses and war abroad. Importantly, the digital space in which online mis- and disinformation circulates connects to on-the-ground lived experiences. Examining how systems of power operate can help us better understand the interplay between technological solutions and broader cultural and social forces.

Finally, the continued proliferation of white supremacy and global ethno-nationalism must be seen as a global problem, not the product of a few "bad actors" and malicious information spread on social media. As we discussed above, these problems are rooted in long histories that require us to trace multiple tendrils of power. The histories of welfare reform and the HIV/AIDS epidemic, for example, offer analysis of how misinformation is connected to inequalities in healthcare and social benefits. Grassroots groups and community-based organizations may serve as models for campaigns that are working not only to disrupt mis- and disinformation through political education, but also to mobilize concrete demands that address broader social conditions of inequality. For instance, Equality Labs, which works within South Asian diasporic communities, has conducted independent research on Islamophobic information spread on Facebook and created multilingual health guides as part of their broader work to dismantle caste and religious hierarchies (2019).

Future interdisciplinary research in critical disinformation studies might bring areas such as history and political economy to the contemporary study of information and platforms (Abhishek, 2021). To strengthen analysis through multi-modal forms of inquiry, we see the possibilities in connecting quantitative research to critical ethnic studies, feminist studies, and science and technology studies, where the politics of knowledge production have been a long-standing site of inquiry (see Chakravartty et al., 2018; Chakravartty \& Jackson, 2020; Kilgo \& Mourão, 2021). We also look to transnational approaches to disinformation that take into consideration cross-cutting geopolitical formations and imperial histories. Such forms of research inquiry have broader political stakes and commitments to social justice and undoing and redressing white supremacy.

Through centering questions of power and grounding inquiry in historical contexts and social difference, a critical approach to disinformation can inform transformational possibilities and address uneven dynamics of power in our digital landscape.

This essay is complementary to Critical Disinformation Studies: A Syllabus developed by the authors, Shanice Jones Cameron and Moira Weigel, with support from the Center for Information, Technology, \& Public Life (CITAP), University of North Carolina at Chapel Hill. 


\section{Bibliography}

Abhishek, A. (2021). Overlooking the political economy in the research on propaganda. Harvard Kennedy School (HKS) Misinformation Review, 2(2). https://doi.org/10.37016/mr-2020-61

Ahmed, S. (2007). A phenomenology of whiteness. Feminist Theory, 8(2), 149-68. https://doi.org/10.1177/1464700107078139

Alamo-Pastrana, C., \& Hoynes, W. (2018). Racialization of news: Constructing and challenging professional journalism as "white media". Humanity \& Society, 44(1), 67-91. https://doi.org/10.1177/0160597618820071

Almeida, S. (2015). Race-based epistemologies: The role of race and dominance in knowledge production. Wagadu: A Journal of Transnational Women's \& Gender Studies, 13, 79-105. https://americanstudies.yale.edu/sites/default/files/files/KnowlProdTeachlnREADING.pdf

Adamson, B. (2016). Thugs, crooks, and rebellious negroes: Racist and racialized media coverage of Michael Brown and the Ferguson demonstrations. Harvard Journal of Racial \& Ethnic Justice, 32, 189-278. https://digitalcommons.law.seattleu.edu/faculty/747

Bayoumi, M. (2015). This Muslim American life: Dispatches from the war on terror. NYU Press.

Bhaman, S. \& Sabal, M. (2020). COVID-19 field notes: How the state \& institutions fail us. In S. Bhaman, R. Kuo, M. Sabal, V. Shaw, \& T. D. Tso (Eds.), Asian American feminist antibodies: Care in the time of Coronavirus (pp. 7-8). https://perma.cc/2MSJ-SE63

Bishop, R. (2000). To protect and serve: The "guard dog" function of journalism in coverage of the Japanese-American internment. Journalism \& Communication Monographs, 2(2), 64-104. https://doi.org/10.1177/152263790000200201

Brier, J. (2009). Infectious ideas: US political responses to the AIDS crisis. University of North Carolina Press.

Cassiman, S. A. (2008). Resisting the neoliberal poverty discourse: On constructing deadbeat dads and welfare queens. Sociology Compass, 2(5), 1690-1700. https://doi.org/10.1111/j.1751$\underline{9020.2008 .00159 . x}$

Carnes, N., \& Lupu, N. (2021). The white working class and the 2016 election. Perspectives on Politics, 19(1), 55-72. https://doi.org/10.1017/S1537592720001267

Chakravartty, P., Kuo, R., Grubbs, V., \& Mcllwain C. (2018). \#CommunicationSoWhite. Journal of Communication, 68(2), 254-266. https://doi.org/10.1093/joc/jqy003

Chakravartty, P. \& Jackson S. (2020). The disavowal of race in communication theory. Communication and Critical/Cultural Studies, 17(2), 210-219. https://doi.org/10.1080/14791420.2020.1771743

Cheng, J.F. (2020). AIDS, women of color feminisms, queer and trans of color critiques, and the crises of knowledge production. In Cheng, J. F., Juhasz, A., \& Shahani, N. (Eds.), AIDS and the distribution of crises (pp.76-92). Duke University Press.

Cohen, C. (1997). Punks, bulldaggers, and welfare queens: The radical potential of queer politics? GLQ 3(4), 437-465. https://doi.org/10.1215/10642684-3-4-437

Collins-Dexter, B. (2020). Canaries in the coal mine: COVID-19 misinformation and black communities. Technology and Social Change Research Project. https://doi.org/10.37016/TASC$\underline{2020-01}$

Coontz, S. (2016, November 11). Why the white working class ditched Clinton. CNN. https://www.cnn.com/2016/11/10/opinions/how-clinton-lost-the-working-classcoontz/index.html

Covert, B. (2019, July 2). The myth of the welfare queen. The New Republic. https://newrepublic.com/article/154404/myth-welfare-queen 
Del Vicario, M., Bessi, A., Zollo, F., Petroni, F., Scala, A., Caldarelli, G., Stanley, H. E., \& Quattrociocchi, W. (2016). The spreading of misinformation online. Proceedings of the National Academy of Sciences, 113(3), 554-559. https://doi.org/10.1073/pnas.1517441113

Densho Digital Repository (2021). Terminology. https://densho.org/terminology/

Du Bois, W. E. B. (1935). The propaganda of history. In Black reconstruction in America: 1860-1880 (pp. 711-730). Free Press.

Dudziak, M. (2011). Cold War civil rights: Race and the image of American democracy. Princeton University Press.

Duru, N. J. (2004). The Central Park Five, the Scottsboro Boys, and the myth of the bestial Black man. Cardozo Law Review, 25, 1315-1364. https://ssrn.com/abstract=814072

Equality Labs. (2019). Facebook India: Towards the tipping point of violence. https://www.equalitylabs.org/facebookindiareport/

Fausset, R., Bogel-Burroughs, N., \& Fazio, M. (2021, March 17). 8 dead in Atlanta spa shootings, with fears of anti-Asian bias. The New York Times. https://www.nytimes.com/live/2021/03/17/us/shooting-atlanta-acworth

Feng, Y., \& Tseng-Putterman, M. (2019). "Scattered like sand": WeChat warriors in the trial of Peter Liang. Amerasia Journal, 45(2), 238-252. https://doi.org/10.1080/00447471.2019.1676610

Flores-Yeffal, N. Y., Vidales, G., \& Martinez, G. (2019). \#WakeupAmerica, \#lllegalsarecriminals: The role of the cyber public sphere in the perpetuation of the Latino cyber-moral panic in the US. Information, Communication \& Society, 22(3), 402-419. https://doi.org/10.1080/1369118X.2017.1388428

Frank, T. (2016, March 7). Millions of ordinary Americans support Donald Trump. Here's why. The Guardian. https://www.theguardian.com/commentisfree/2016/mar/07/donald-trump-whyamericans-support

Frazier, R. T. (2014) The east Is Black: Cold War China in the Black radical imagination. Duke University Press.

Freelon, D., \& Wells, C. (2020). Disinformation as political communication. Political Communication, 37(2), 145-156. https://doi.org/10.1080/10584609.2020.1723755

Freelon, D., Bossetta, M., Wells, C., Lukito, J., Xia, Y., \& Adams, K. (2020). Black trolls matter: Racial and ideological asymmetries in social media disinformation. Social Science Computer Review. https://doi.org/10.1177/0894439320914853

Friedberg, B., \& Donovan, J. (2020, August 11). Viral slogan: "It's OK to be white." The Media Manipulation Casebook. https://mediamanipulation.org/case-studies/viral-slogan-its-ok-bewhite

Gibson, A. N., \& Martin, J. D. (2019). Re-situating information poverty: Information marginalization and parents of individuals with disabilities. Journal of the Association for Information Science and Technology, 70(5), 476-487. https://doi.org/10.1002/asi.24128

Hall, S. (1977). Culture, the media and the ideological effect. In J. P. Curran, M. Gurevitch, \& J. Woollacott (Eds.), Mass Communication and Society (pp. 315-348). Edward Arnold.

Harris, C. (1993). Whiteness as property. Harvard Law Review, 106(8), 17071791. https://doi.org/10.2307/1341787

Hughes, S. (2017). American monsters: Tabloid media and the satanic panic, 1970-2000. Journal of American Studies, 51(3), 691-719. https://doi.org/10.1017/S0021875816001298

Japanese American Citizens League (2013, April 27). The power of words: A guide to language about Japanese Americans in World War II. https://jacl.org/power-of-words

Jardina, A. (2019). White consciousness and white prejudice: Two compounding forces in contemporary American politics. The Forum, 17(3), 447-466. https://doi.org/10.1515/for-2019-0025 
Juhasz, A. (1995). AIDS TV: Identity, community, and alternative video. Duke University Press.

KhudaBukhsh, A. R., Sarkar, R., Kamlet, M. S., \& Mitchell, T. M. (2021). Fringe news networks: Dynamics of US news viewership following the 2020 presidential election. ArXiv. http://arxiv.org/abs/2101.10112

Kilgo, D. K. \& Mourão, R. R. (2021). Protest coverage matters: How media framing and visual communication affects support for Black civil rights protests. Mass Communication and Society, 24(4), 576-596. https://doi.org/10.1080/15205436.2021.1884724

Kreiss, D. (2021). Social media and democracy: The state of the field, prospects for reform. The International Journal of Press/Politics, 26(2), 505-512. https://doi.org/10.1177/1940161220985078

Kreiss, D., Lawrence, R. G., \& McGregor, S. C. (2020). Political identity ownership: Symbolic contests to represent members of the public. Social Media + Society, 6(2). https://doi.org/10.1177/2056305120926495

Kreiss, D., \& McGregor, S. C. (2021, April 5). Polarization isn't America's biggest problem-Or Facebook's. Wired. https://www.wired.com/story/polarization-isnt-americas-biggest-problemor-facebooks/

Kumar, D. (2006). Media, war, and propaganda: Strategies of information management during the 2003 Iraq War. Communication and Critical/Cultural Studies, 3(1), 48-69. https://doi.org/10.1080/14791420500505650

Kundnani, A. (2014). The Muslims are coming! Islamophobia, extremism and the domestic war on terror. Verso Books

Lavin, T. (2020, September 29). QAnon, blood libel, and the satanic panic. The New Republic. https://newrepublic.com/article/159529/qanon-blood-libel-satanic-panic

Marwick, A. \& Lewis, R. (2017). Media manipulation and disinformation online. Data \& Society. https://datasociety.net/pubs/oh/DataAndSociety MediaManipulationAndDisinformationOnline. pdf

Marwick, A. \& Partin, W. (2020, October 5). QAnon shows that the age of alternative facts will not end with Trump. Columbia Journalism Review. https://www.cjr.org/opinion/qanon-trumpalternative-facts.php

Marwick, A., Kuo, R., Cameron, S. J., \& Weigel, M. (2021). Critical disinformation studies: A syllabus. Center for Information, Technology and Public Life. https://citap.unc.edu/wpcontent/uploads/sites/20665/2021/03/Marwick Kuo Cameron Weigel 2021 CriticalDisinform ationStudiesSyllabus.pdf

McKinney, C. (2020). Crisis infrastructures: AIDS activism meets internet regulation. In Cheng, J. F., Juhasz, A., \& Shahani, N. (Eds.), AIDS and the distribution of crises (pp. 162-182). Duke University Press.

McMillan Cottom, T. (2020). Where platform capitalism and racial capitalism meet: The sociology of race and racism in the digital society. Journal of Race and Ethnicity, 6(4), 441-449. https://doi.org/10.1177/2332649220949473

Mejia, R., Beckermann, K., \& Sullivan, C. (2018). White lies: A racial history of the (post)truth. Communication and Critical/Cultural Studies, 15(2), 109-126. https://doi.org/10.1080/14791420.2018.1456668

Mutz, D. C. (2018). Status threat, not economic hardship, explains the 2016 presidential vote. Proceedings of the National Academy of Sciences, 115(19), E4330-E4339. https://doi.org/10.1073/pnas.1718155115

Nguyen, N. (2019). Suspect communities: Anti-Muslim racism and the domestic war on terror. University of Minnesota Press. 
Nkonde, M., Rodriguez, M. Y., Cortana, L., Mukogosi, J. K., King, S., Serrato, R., Martinez, N., Drummer, M., Lewis, A., \& Malik, M. M. (2021). Disinformation creep: ADOS and the strategic weaponization of breaking news. Harvard Kennedy School (HKS) Misinformation Review, 1(7). https://doi.org/10.37016/mr-2020-52

Noble, S. (2014). Teaching Travyon: Race, media, and the politics of spectacle. The Black Scholar, 44(1), 12-29. https://doi.org/10.1080/00064246.2014.11641209

Noble, S. (2017, January 15). Google and the misinformed public. Chronicle of Higher Education. https://www.chronicle.com/article/google-and-the-misinformed-public/

Noel, T. K. (2020). Conflating culture with COVID-19: Xenophobic repercussions of a global pandemic. Social Sciences \& Humanities Open, 2(1), 1-7. https://doi.org/10.1016/i.ssaho.2020.100044

Ong, J. C. (2021, February 4). The contagion of stigmatization: Racism and discrimination in the "Infodemic" moment. MediaWell Social Science Research Council. https://mediawell.ssrc.org/literature-reviews/the-contagion-of-stigmatization-racism-anddiscrimination-in-the-infodemic-moment/versions/1-0/

Pasquetto, I. (2020). All disinformation is local: A reflection on the need and possibility of measuring impact [Editorial]. Harvard Kennedy School (HKS) Misinformation Review 1(6).

https://misinforeview.hks.harvard.edu/article/do-we-really-need-to-measure-the-impact-ofonline-disinformation/

Peck, R. (2019). Fox populism: Branding conservatism as working class. Cambridge University Press.

Phillips, W. \& Milner, R. M. (2021). You are here: A field guide for navigating polarized speech, conspiracy theories, and our polluted media landscape. MIT Press.

Polletta, F., \& Callahan, J. (2017). Deep stories, nostalgia narratives, and fake news: Storytelling in the Trump era. American Journal of Cultural Sociology, 5, 392-408. https://doi.org/10.1057/s41290$\underline{017-0037-7}$

Perez, T. L., \& Dionisopoulos, G. N. (1995). Presidential silence, C. Everett Koop, and the surgeon general's report on AIDS. Communication Studies, 46(1-2), 18-33. https://doi.org/10.1080/10510979509368436

Read, M. (2016, November 9). Donald Trump won because of Facebook. New York Magazine. https://nymag.com/intelligencer/2016/11/donald-trump-won-because-of-facebook.html

Said, E. (1978). Orientalism. New York: Vintage Books.

Saranillio, D. I. (2018). Unsustainable empire: Alternative histories of Hawai'i statehood. Duke University Press.

Schaffner, B. F., MacWilliams, M., \& Nteta, T. (2018). Understanding white polarization in the 2016 vote for president: The sobering role of racism and sexism. Political Science Quarterly, 133(1), 9-34. https://doi.org/10.1002/polq.12737

Shah, N. (2001). Contagious divides: Epidemics and race in San Francisco's Chinatown. University of California Press.

Sides, J., Tesler, M. \& Vavreck, L. (2018). Identity crisis: The 2016 presidential campaign and the battle for the meaning of America. Princeton University Press.

Snow, N., \& Taylor, P. M. (2006). The revival of the propaganda state: US propaganda at home and abroad since 9/11. International Communication Gazette, 68(5-6), 389-407. https://doi.org/10.1177\%2F1748048506068718

Solon, O. (2016, November 10). Facebook's failure: Did fake news and polarized politics get Trump elected? The Guardian. https://www.theguardian.com/technology/2016/nov/10/facebook-fakenews-election-conspiracy-theories

Staples, B. (2021, July 10). How the white press wrote off Black America. The New York Times. https://www.nytimes.com/2021/07/10/opinion/sunday/white-newspapers-africanamericans.html 
Tripodi, F. (2018). Searching for alternative facts: Analyzing scriptural inference in conservative news practices. Data \& Society. https://datasociety.net/library/searching-for-alternative-facts/

Trouillot, M. R. (1995). Silencing the past: Power and the production of history. Beacon Press.

Tufekci, Z. (2019, April 22). How recommendation algorithms run the world. Wired. https://www.wired.com/story/how-recommendation-algorithms-run-the-world/

Tuhiwai Smith, L. (1999). Decolonizing methodologies: Research and Indigenous peoples. Zed Books.

Tuters, M. \& Hagen, S. (2019). (((They))) rule: Memetic antagonism and nebulous othering on 4chan. New Media and Society, 22(12), 2218-2237. https://doi.org/10.1177\%2F1461444819888746

Vosoughi, S., Roy, D., \& Aral, S. (2018). The spread of true and false news online. Science, 359(6380), 1146-1151. https://doi.org/10.1126/science.aap9559

Washington, A. \& Kuo, R. (2020). Whose side are ethics codes on? Power, responsibility and the social good. Proceedings of the 2020 Conference on Fairness, Accountability, and Transparency (FAT'20), pp. 230-340. htps://doi.org/10.1145/3351095.3372844

Worland, J. (2020, October 20). How the Trump campaign Is trying to suppress the Black vote. Time. https://time.com/5902729/black-voter-suppression-2020/ 


\section{Copyright}

This is an open access article distributed under the terms of the Creative Commons Attribution License, which permits unrestricted use, distribution, and reproduction in any medium, provided that the original author and source are properly credited. 